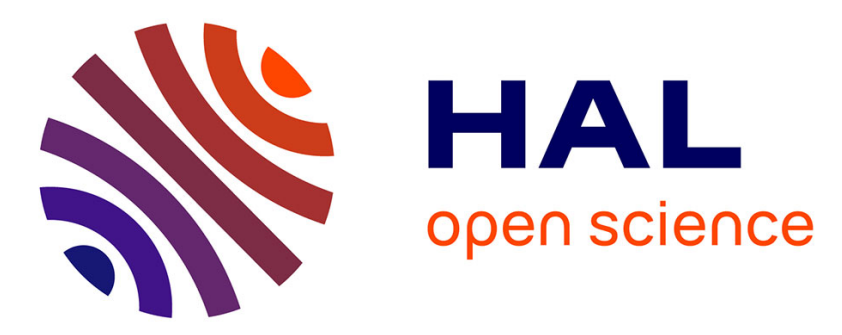

\title{
Electronic environment for a field emission gun in electron microscopy
}

H. Pinna, K. Liang, M. Denizart, B. Jouffrey

\section{To cite this version:}

H. Pinna, K. Liang, M. Denizart, B. Jouffrey. Electronic environment for a field emission gun in electron microscopy. Revue de Physique Appliquée, 1983, 18 (10), pp.659-665. 10.1051/rphysap:019830018010065900 . jpa-00245128

\section{HAL Id: jpa-00245128 https://hal.science/jpa-00245128}

Submitted on 1 Jan 1983

HAL is a multi-disciplinary open access archive for the deposit and dissemination of scientific research documents, whether they are published or not. The documents may come from teaching and research institutions in France or abroad, or from public or private research centers.
L'archive ouverte pluridisciplinaire HAL, est destinée au dépôt et à la diffusion de documents scientifiques de niveau recherche, publiés ou non, émanant des établissements d'enseignement et de recherche français ou étrangers, des laboratoires publics ou privés. 
Classification

Physics Abstracts

07.80

\title{
Electronic environment for a field emission gun in electron microscopy
}

\author{
H. Pinna, K. Liang (*), M. Denizart and B. Jouffrey \\ Laboratoire d'Optique Electronique du C.N.R.S., associé à l'Université Paul Sabatier, B. P. 4347, \\ 31055 Toulouse Cedex, France
}

(Reçu le 10 février 1983, révisé le 23 juin, accepté le 12 juillet 1983)

\begin{abstract}
Résumé. - En microscopie électronique, un canon à émission de champ est particulièrement intéressant par sa très grande brillance et la faible dispersion en énergie du faisceau électronique. Cependant, son emploi qui s'avère très délicat, nous a amenés à concevoir et réaliser un environnement électronique.

Cet article décrit l'alimentation de l'anode d'extraction, dont la polarité peut être inversée afin de remodeler la pointe, le dispositif de chauffage de celle-ci permet son nettoyage ainsi que l'émission en température ambiante (T.A.) et l'émission assistée (T.F.). Un soin particulier a été porté pour la protection de la pointe et des alimentations, car ce type de canon est fréquemment le siège de phénomènes disruptifs. Une des difficultés de son utilisation est due à l'instabilité du courant émis. L'étude d'un asservissement de la tension d'extraction à la valeur du courant émis total ou partiel est abordée.
\end{abstract}

\begin{abstract}
The high brightness, the low energy spread and the small diameter of the source given by a field emission gun is particularly interesting in electron microscopy.

This paper describes the extracting anode supply, the polarity of which may be reversed in order to remolde the tip. The heating device of the tip enables its cleaning, the room temperature emission, and also the temperature and field emission. A particular attention has been paid to the protection of the tip and supplies, because of the numerous disruptive breakdowns which can occur in that type of gun. The fluctuations of the emitted current are one of the difficulties encountered with this kind of source. The study of the current feedback control which drives the extracting voltage generator with respect to the total current or partial current emitted is dealed.
\end{abstract}

\section{Introduction.}

The field emission electron sources have well known interesting properties. Under certain conditions, it is possible to obtain a brightness greater than $10^{8} \mathrm{~A} \cdot \mathrm{cm}^{-2} \cdot \mathrm{Sr}^{-2}$, an energy spread of about $0.2 \mathrm{eV}$ and an effective source radius of a few tens of $\AA$ [1-4].

However, it is very difficult to achieve a sufficiently stable and high beam current. If the lifetime of the cathode is very important when the gun is used as a simple diode (low accelerating voltage), it may be very short when the gun is placed on an electron microscope with a fixed or a scanned beam working at high voltage ( $100 \mathrm{kV}$ or more). In this case, the instabilities of the current may cause the destruction of the tip by disruptive breakdowns, and damage electric supplies. These ones would be able to achieve the polarization of the cathode with respect to the anode for the electron emission or for the remolding

$\left({ }^{*}\right)$ Control Engineering Institute, B. P. 2729, Pekin, China. of the tip, but also the heating of the tip, either during its cleaning or during its remolding or also when the field emission source is thermally enhanced.

The specifications required for the electronic environment of the gun are determined with respect to its effect on the stability of the emitted current and to the optical properties of the gun $[1,6]$. The output voltage of the $V_{1}$ supply (see Fig. 1) is specified to be continuously variable from 0 to $12 \mathrm{kV}$ and from 0 to $-8 \mathrm{kV}$, with a maximum emitted current of $100 \mu \mathrm{A}$. The optical properties of the gun are not degraded by an instability of $10 \mathrm{ppm}$. At last this supply is specified to produce no overshoot.

The tip flasher is specified to generate a current ranging from 1 to $5 \mathrm{~A}$ for a filament diameter of $0.12 \mathrm{~mm}$. The current passing through the filament produces a magnetic field which displaces the beam [3]. For tip anode distances of $2 \mathrm{~mm}$, the broadening of the source can be neglected when the current instability is lower than $100 \mathrm{ppm}$. The current must be direct or in pulses which are adjustable from 1 to $5 \mathrm{~s}$. 


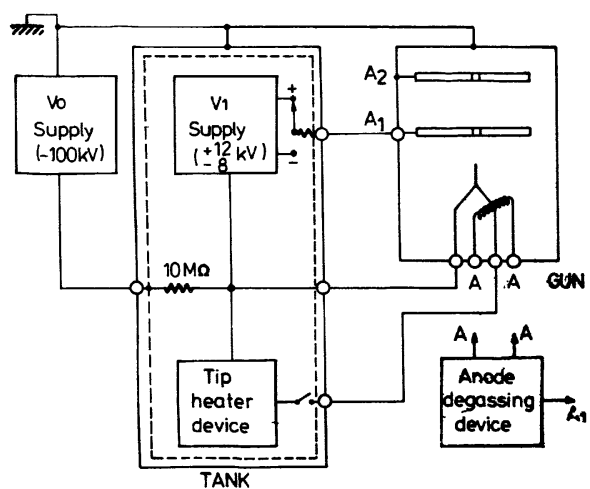

Fig. 1. - Simplified block diagram of the system.

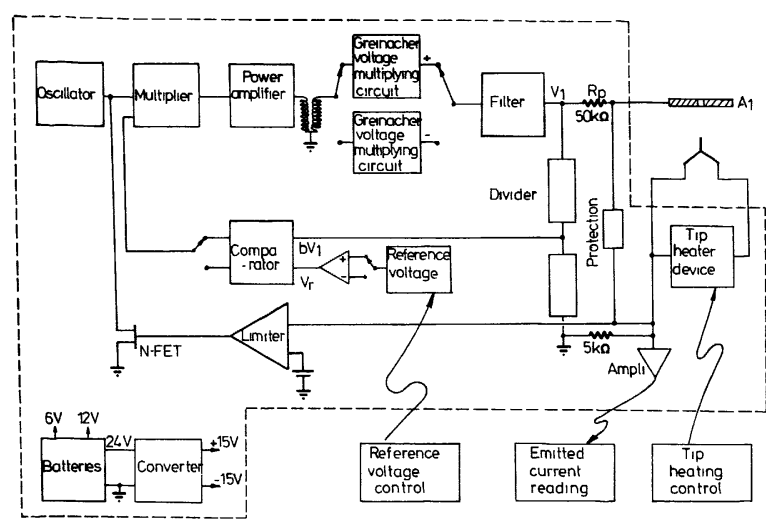

Fig. 2. - Functional diagram of the system.

A block diagram of the system is shown on figure 2 . The control of $V_{1}$ and the control of the tip heating current are operated through an optical data link.

The total current emitted by the tip passes through a resistance placed between the power ground of the two supplies. The voltage across the resistance is converted and transmitted by an optical fiber path. So it is possible to know accurately the value of the emitted current, and also to monitor it by controlling the output voltage of the $V_{1}$ supply.

Rechargeable sealed nickel-cadmium batteries are used as energy source. Their capacity is $7 \mathrm{Ah}$ and they are recharged during the night. The adaptation of this system on the field emission gun is described in the last part, and the first results are given.

\section{First anode supply.}

2.1 Circuit operation. - The operation of the regulation loop of this supply may be analysed on the figure 2. A fraction $b V_{1}$ of the voltage produced by the aperiodic resistive divider is compared to the voltage reference $V_{\mathrm{R}}$. The error voltage $\left(V_{\mathrm{R}}-b V_{1}\right)$, amplified by the comparator, controls the gain of a multiplier, the second input of which is connected to an oscillator. The output signal of the multiplier is amplified and rectified by the Greinacher voltage multiplying circuit. Its polarity can be reversed by commutation.

The supply circuit detailed diagram is shown on the figure 3 . The polarity is modified, by reversing the reference voltage and the control voltage of the multiplier. When the voltage is positive, the transistor $\mathrm{T}_{1}$ controls the precision integrated four quadrant analog multiplier (ICL 8013) from 0 to $8 \mathrm{~V}$, and the transistor $\mathrm{T}_{2}$ from 0 to $-5 \mathrm{~V}$ when the voltage is negative.

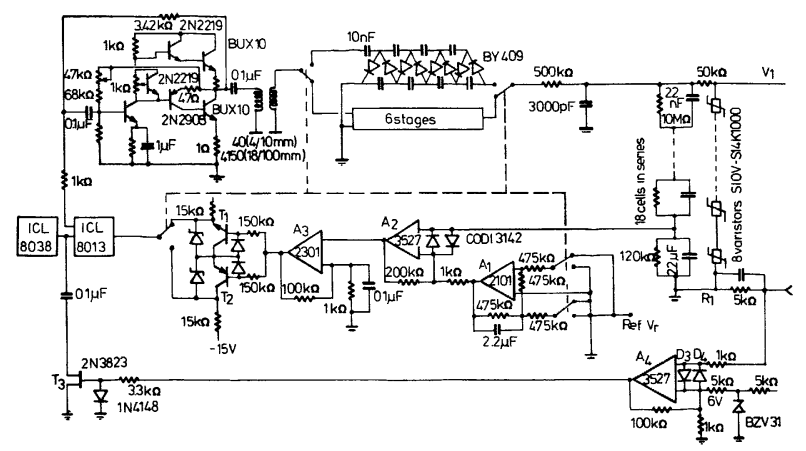

Fig. 3. $-V_{1}$ supply circuit detailed diagram.

The value of the ripple voltage on $V_{1}$ is given by [7] :

$$
\begin{aligned}
& \Delta V= \pm\left(i / f C_{\mathrm{M}}\right) N(N+2) \\
& \Delta V=32,2 \mathrm{~V} \text { peak to peak } .
\end{aligned}
$$

Here, $i$ is the load current $(166 \mu \mathrm{A}), f$ the operating frequency $(\simeq 100 \mathrm{kHz}), N$ the number of stages. $\Delta V$ is reduced at $4 \mathrm{ppm}$ by a low-pass filter.

2.2 Materials. - The specifications of the supply depend directly on the aperiodic divider characteristics, on the reference, and on the comparator amplifier $\mathbf{A}_{2}$. This low drift operational amplifier equipped with a low bias current Field Effect Transistor (FET) diverts a negligeable current from the aperiodic divider. His offset voltage temperature drift is low $\left(2 \mu \mathrm{V} /{ }^{\circ} \mathrm{C}, \max \right)$. It is the same for the ultra-low leakage silicon diodes (Codi C3142) that protect the same comparator and the limiter.

Since there is a great probability for the high voltage discharges, a particular attention has been paid to the protection, the differents elements of which are :

- An emitted current limiter at $100 \mu \mathrm{A}$, consisting in the $\mathrm{A}_{4}$ amplifier and a $\mathrm{T}_{3}$ FET.

- The protection resistance $R_{p}$.

- Some metal zinc-oxide varistor (SIOV) which are voltage dependent resistors $\left(\mathrm{VDR}_{\mathrm{s}}\right)$. Their resistance decreases when voltage is increased and the response time is less than $25 \mathrm{~ns}$.

- Some surge voltage protectors, at the terminals of which the voltage falls down at a few volts in less than $250 \mathrm{~ns}$. 
Varistors and surge voltage protectors, have been arranged in parallel, between the tip and the first anode and protect the tip and the supply, when a discharge happens between the two anodes. At first, the voltage is limited to about $10 \mathrm{kV}$ by the varistors, then, the voltage falls down to about $10 \mathrm{~V}$ by the action of the surge voltage protectors. Moreover, if the supply is far away from the gun, when a breakdown voltage happens at one end of the connection wire, it may produce in it a very high surge. For this reason, the protection elements, will be set in the connection head of the gun and in the supply.

- Some Transient Absorber Zener, the response time of which is very short (1 ps), that can absorb high power pulses, protect many components in the supplies.

2.3 Closed-LOOP TRANSFER FUNCTION OF THE $V_{1}$ SUPPLY. - The performances of the $V_{1}$ supply are essentially determined by those of the loop of the feedback control system shown on the figure 4 . The transfer function of the loop is :

$$
F(p)=\frac{73,333(1+p / 4,500)}{(1+p / 25)(1+p / 66)}
$$

$p$ is a Laplace variable.

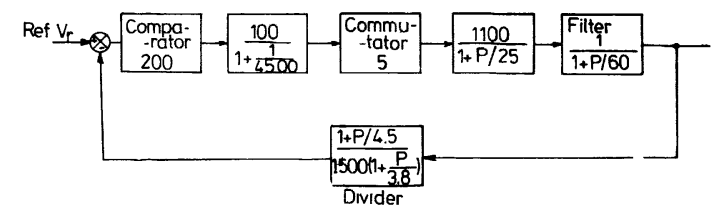

Fig. 4. - Transfer function of the $V_{1}$ supply.

This transfer function shows that the loop is stable and that the position error is very low. The instability of our supply is lower than $7 \mathrm{ppm}$ for $15 \mathrm{~min}$. and $50 \mathrm{ppm}$ for $14 \mathrm{~h}$. is :

The expression of the closed loop transfer function

$$
H g(p)=\frac{1,500(1+p / 4,500)}{1+2 \times 1.22 p / 11,000+p^{2} /(11,000)^{2}} .
$$

It behaves like a 2 nd order circuit, the factor damping $z$ of which is equal to 1.22 . This value, greater than the critical value $(z=1)$, guarantees a step response without overshooting.

\section{Remote control by an optical fiber cable.}

The controls of the $V_{1}$ supply reference voltage and of the heating tip supply are operated by an optical fiber data link; a same link is used to know the value of the emitted current. In addition to the electrical insulation, this transmission offers an excellent immunity against the environmentals influencies and it is possible to achieve a very good accuracy, when the best available components are used. The necessary elements for such a link are indicated on figure 5. The performances depend only on the converters.

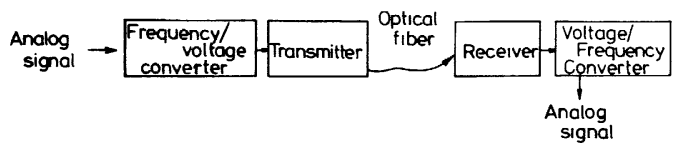

Fig. 5. - Simplified block diagram of the optical fibre link.

3. $1 V_{1}$ SUPPLY REFERENCE VOLTAGE CONTROL. - The components used for the construction of the $V_{1}$ supply remote control have been carefully selected. This can be observed on figure 6. A part of the $10 \mathrm{~V}$ precision reference output (AD 2700) is converted to a frequency ranging from 0 to $100 \mathrm{kHz}$ by a high accurate voltage to frequency converter $(458 \mathrm{~K})$. The noise (peak to peak) and the gain drift are respectively equal to $4 \mathrm{ppm}$ and $6 \mathrm{ppm}$. The dynamics characteristics of this transmission are defined by the maximum value desired for the ripple voltage. Thus, it has been insert a first order low pass filter the natural frequency of which is equal to $0.5 \mathrm{~Hz}$.

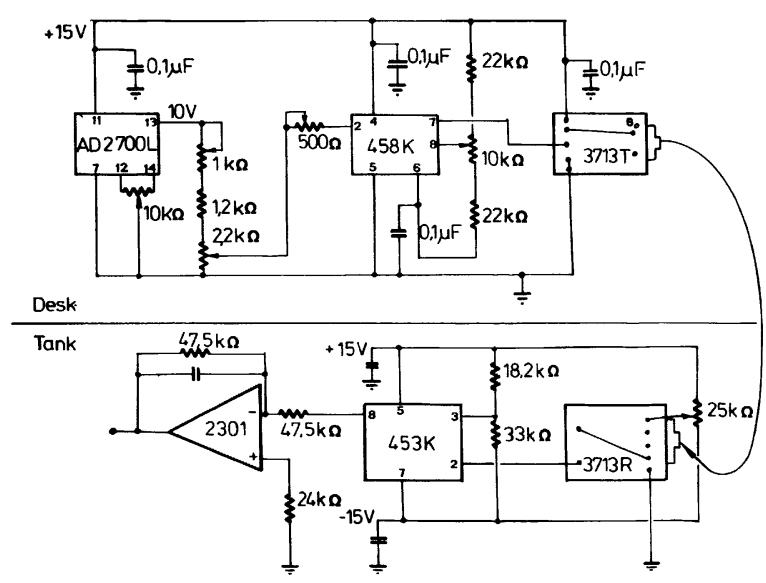

Fig. 6. - Circuit detailed diagram of the $V_{1}$ supply reference voltage control.

3.2 TIP HEATER SUPPLY REFERENCE VOLTAGE CONTROL. - The functional diagram of the tip heater system is given on figure 7. The oscillator (8038) generates a square wave, frequency of which can be varied from $1 \mathrm{kHz}$ to $100 \mathrm{kHz}$. The voltage reference corresponding to this signal varies from $2.4 \mathrm{mV}$ to $240 \mathrm{mV}$. The performance of this link enables to obtain a relative stability of about $10^{-5}$.

The heating time of the tip is checked by a logical gate $(410 \mathrm{E})$. The 3 positions of the commutator correspond to the field emission, to the cleaning of the tip obtained with pulses ranging from 0.5 to $5 \mathrm{~s}$ and, at last, to the thermal field emission. 


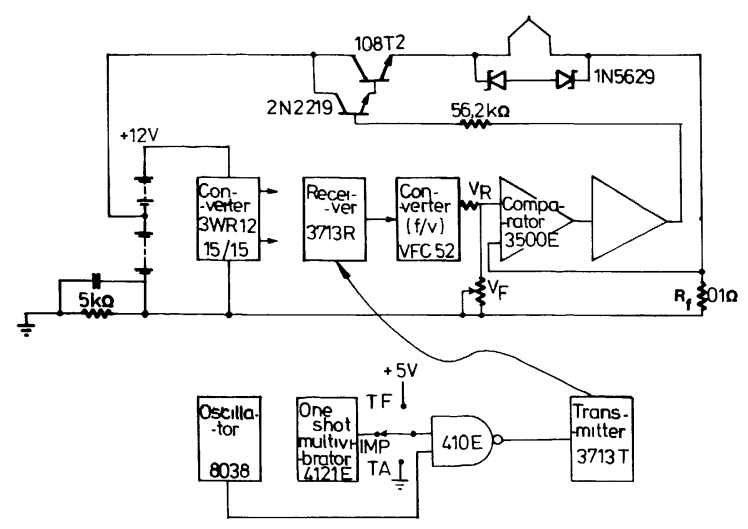

Fig. 7. - Functional diagram of the tip heater system.

3.3 READING THE EMITTED CURRENT. - The components used for the reading of the total emitted current have lower performances. The voltage given by a Frequency-Voltage Converter (VFC 52) located in a desk control, is connected to a digital voltmeter and to a comparator (Fig. 8).

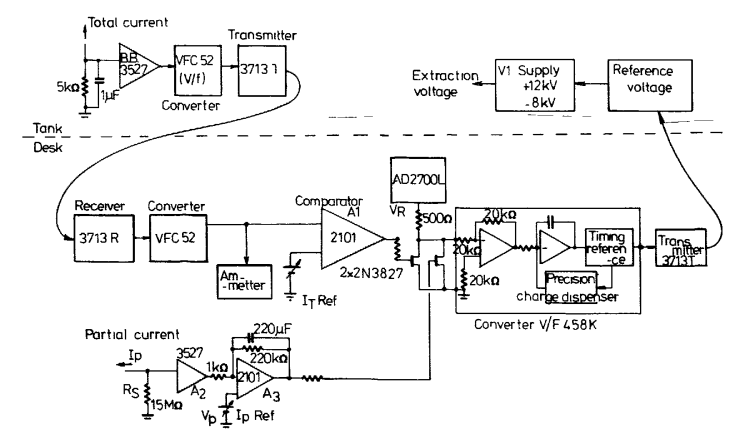

Fig. 8. - Block diagram of the total current reading system and the current feedback control system.

This comparator is set in a system which acts as a limiter. When the emitted current is lower than a desired value, the output voltage of the $\mathrm{A}_{1}$ comparator is blocked, so the field effect transistor (2N3827) is equivalent to an open circuit. When the emitted current is greater than the desired value, this transistor deducts current on the Voltage-Frequency Converter input, so that the reference voltage decreases, and the value of the total current emitted is regulated at the chosen value. In such conditions, this system works as a feedback control system. Nevertheless, the partial currents collected either on a diaphragm or in a Faraday cage are not sufficiently stabilized. This is a consequence of the relations linking the total current and the partial current $[8,9]$.

Interesting rates of stabilization [10] have been obtained with the feedback control system shown figure 8 . The partial current is converted to a voltage which is magnified by $\mathrm{A}_{2}$, then compared to a voltage reference $V_{\mathrm{p}}$ by means of $\mathrm{A}_{3}$. This amplifier and the transistor $2 \mathrm{~N} 3827$ drive the input voltage of the
Voltage-Frequency Converter. Thus, the $V_{1}$ voltage follows the beam current fluctuations.

\section{System design.}

The ground circuit of the electron gun supplies is polarized at the high voltage $V_{0}$. The insulation of these supplies with respect to the earth is a first problem to solve. For reducing the volume, the electronics have been designed to work in a gasfilled tank. The supplies are set in a tank and the gas is pressurized at 30 psi. In this way, the thermal dissipation decreases particularly when the nickelcadmium cells are recharged; figure 9 and figure 10 represent the device. All electronic parts are shielded and corona protected by the hot-top enclosure. This electrostatic screen is hung to an insulating support, in which five gas-tight wells allow to connect the supplies to the gun. One hole is used for recharging the cells.

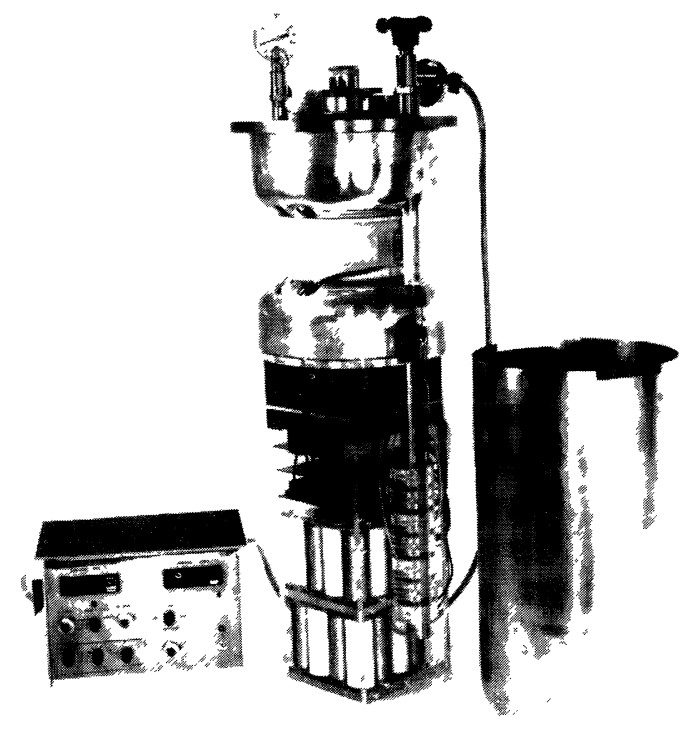

Fig. 9. - Electronic environment.

The optical fibers surrounding the support, insure the remote control between the desk and the supplies. As a general rule, the radius of curvature are greater than $2.5 \mathrm{~cm}$, while the minimum break path has been kept at $13 \mathrm{~cm}$. The screen and the tank are separated by a distance of $5 \mathrm{~cm}$.

To have a sufficient reliability, air has been replaced by freon 12, the price of which is lower than SF6. It also permits to work at $50 \mathrm{psi}$.

Difficulties related to the increase of the temperature of the components have been solved by making a series of holes in the electrostatic screen and in the cell support; the outside of the tank and the inside 

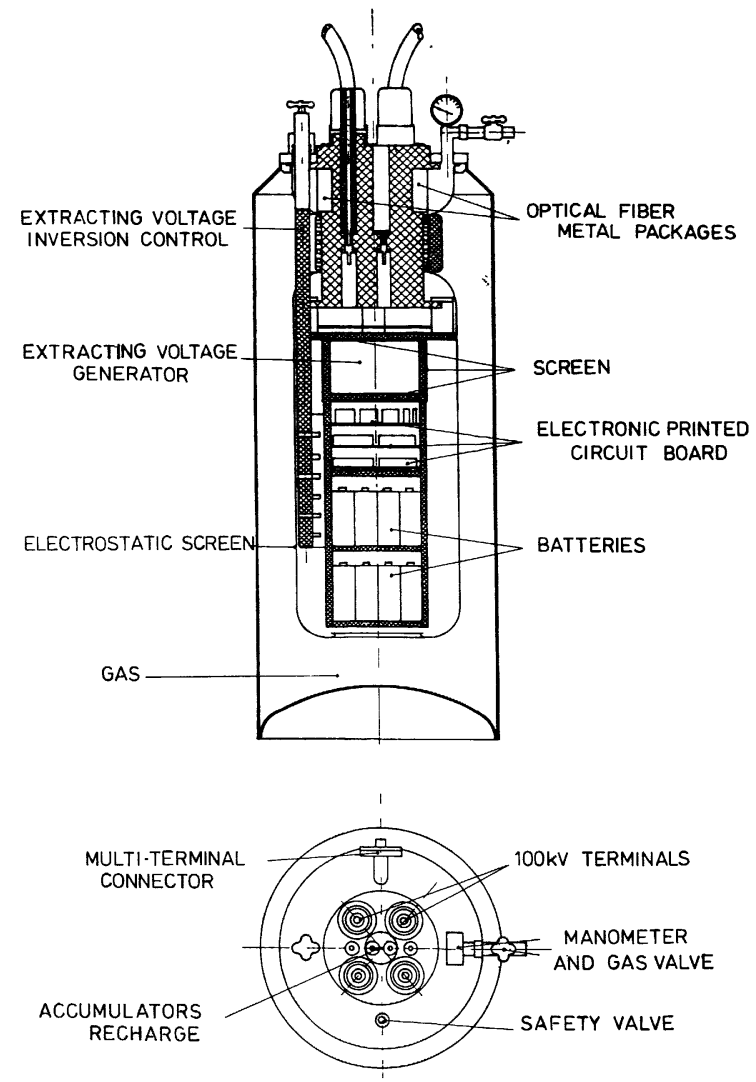

Fig. 10. - Cross section of the tank.

of the screen are black painted; a stainless steel plate is inserted between electronic circuits and accumulators. The value of the batteries recharge current is $0.4 \mathrm{~A}$ limited. So the temperature rise near the batteries does not exceed $30^{\circ} \mathrm{C}$.

\section{Adaptation on a gun.}

\section{1 Regulation lOOP OF THE EMITTED CURRENT. -} The so described device has been completed by a loop which allows either the regulation of the total emitted-current $\left(I_{\mathrm{T}}\right)$, either the regulation of the current collected on the anode $\left(I_{\mathrm{A}}\right)$ or the regulation of the current $\left(I_{\mathrm{F}}\right)$ collected in a Faraday cup located beyond the anode (Fig. 11).

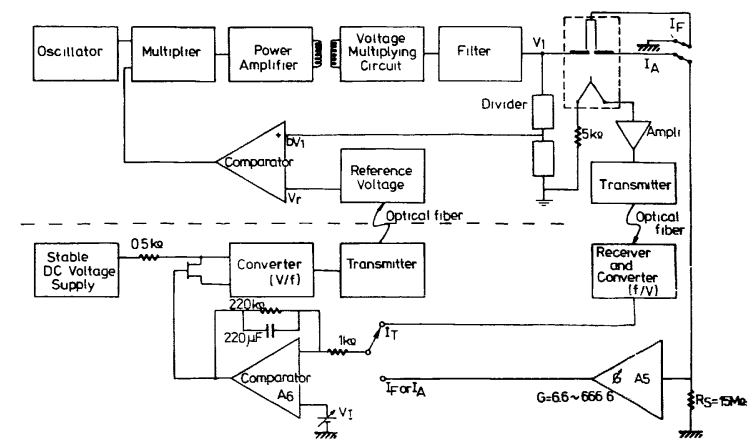

Fig. 11. - Current feedback control system.

REVUE DE PHYSIQUE APPLIQUÉE. - T. 18, No 10, OCTOBRE 1983
The transfer function of the system is shown in figure 12. For typical working conditions, the gun can be characterized by an admittance of $2 \times 10^{-2} \mathrm{M} \Omega^{-1}$ when the $I_{\mathrm{T}}$ current is regulated or by an admittance of $2 \times 10^{-4} \mathrm{M}^{-1}$ when the $I_{\mathrm{F}}$ current is regulated. The characteristics of this feedback control system are able to compensate the transmittance variations of the gun.

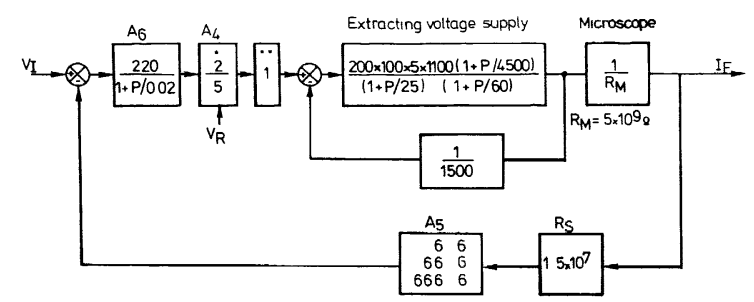

Fig. 12. - Transfer function of the control system. * The transistor $2 \mathrm{~N} 3827$ works as a multiplicator, ${ }^{* *}$ the optical fibre works as a voltage follower.

The evaluation of the system properties has been achieved using the experimental device shown in figure 11 and the curves in figures 13 and 14 display its efficiency.

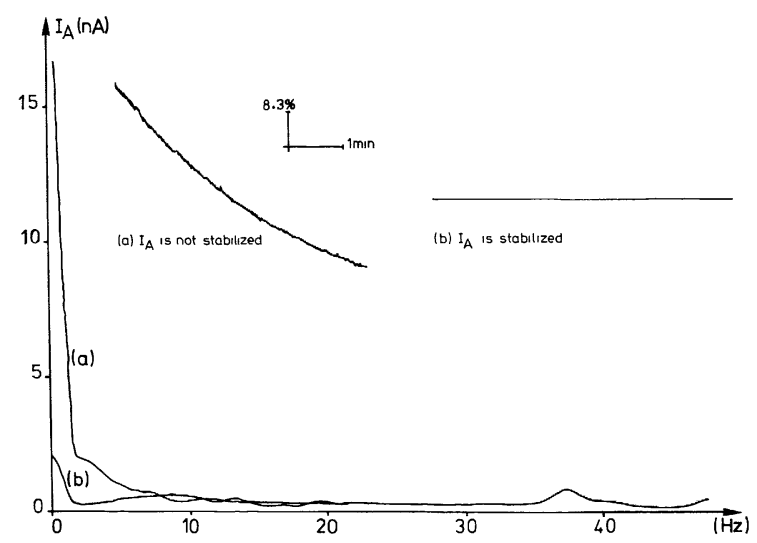

Fig. 13. - Stability of the current received on the extracting anode $\left(I_{\mathrm{A}}=300 \mathrm{nA}\right)$. Corresponding $I_{\mathrm{A}}$ current spectrum (B.N. $=1.45 \mathrm{~Hz}$ ).

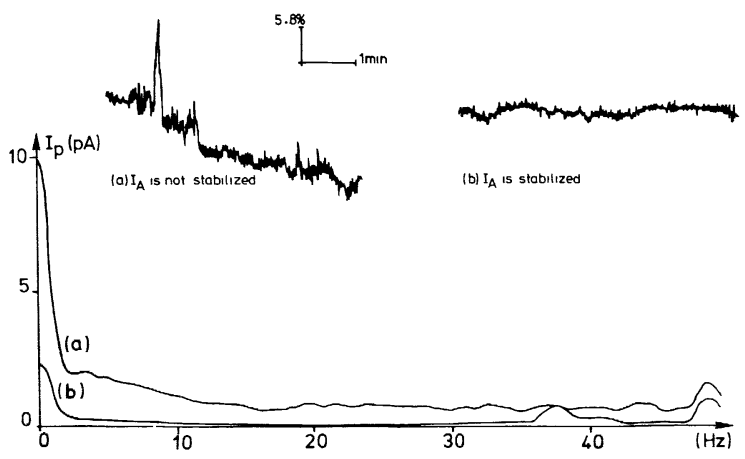

Fig. 14. - Stability of the $I_{\mathrm{F}}$ current when $I_{\mathrm{A}}$ is (or is not) stabilized. Corresponding $I_{\mathrm{F}}$ current spectrum (B.N. = $1.45 \mathrm{~Hz})\left(I_{\mathrm{F}}=1.14 \mathrm{nA}\right)$. 
One can see that the power spectral density increases very sensitively when the frequency decreases and particularly under a ten of Hertz owing to the fact that the drift and the ripple have greatest components for the low frequencies. Figures 13 and 14 obviously show that a bandwidth of a few tens of Hertz of the feedback control system is sufficient to get an efficient stabilization of the emitted current, which components of frequencies lower than $10 \mathrm{~Hz}$ are strongly reduced [11].

5.2 INFLUENCE OF THE STABILIZATION ON THE OPTICAL PROPERTIES OF THE GUN. - In electron microscopy one of the most important problem is to obtain such an optical adjustment that it will not be necessary to change it during the observations. Now, the optical properties of a field emission gun depend on the values of the voltages applied to the different electrodes. So, it can be thought that the kind of stabilization that have been described, would have bad influence on the optical properties [12]. However, the studies

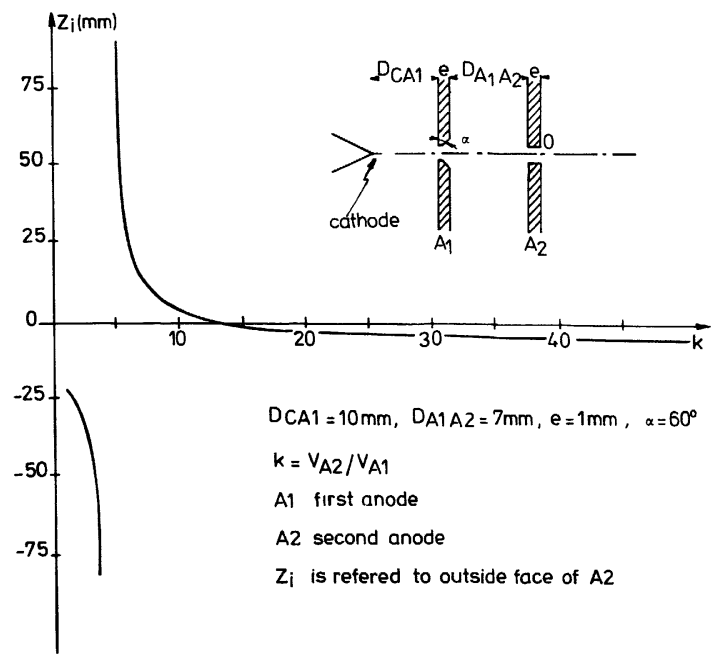

Fig. 15. - Position of the source given by a triode field emission gun.
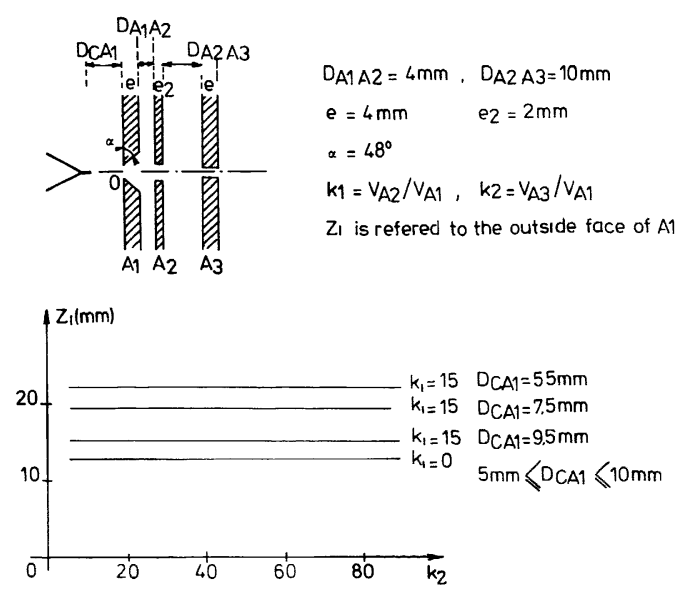

Fig. 16. - Position of the source given by a tetrode field emission gun. of the electrooptical properties of the triode field emission guns (the tip is followed by two anodes) and of the tetrode field emission guns (the tip is followed by three anodes) show that those objections are not really based. For those guns we have shown that for some geometries of the anodes [9, 13], it is possible to get a stable position and a fixed diameter of the source whatever the working conditions will be, as shown in figures 15 and 16 for the position of the source given either by a triode gun (Fig. 15) or by a tetrode gun (Fig. 16). In the case of the triode corresponding to the figure 15 for a typical mean value of the extracting voltage of $3 \mathrm{kV}$ and accelerating voltage greater than $30 \mathrm{kV}$, it can be seen that the source position is practically independent of $k=V_{\mathrm{ac}} / V_{\mathrm{ex}}$.

In the case of the tetrode gun corresponding to the figure 16 it can be seen that for two values of $k_{1}$ (ratio of the second anode voltage to the first anode voltage) : $k_{1}=0$ or, $k_{1}=15$, the source position is independent of the ratio $k_{2}$ of the third anode voltage (accelerating voltage) to the first anode voltage (extracting voltage).

However we have no order of magnitude on the influence of the voltage variations on the centring (transverse shift) even if it can be thought that it will be rather small.

So taking into account that, a relative variation of the emitted current of $18 \%$ can be compensated by a corresponding variation of the extracting voltage of $1 \%$, it can be said that this stabilization has no influence on the optical properties of our guns [14].

\section{Conclusion.}

The field emission gun advantages are now generally admitted and such sources are more and more used. Nevertheless, their use is critical and they request very strict experimental conditions. So it is absolutely necessary to have a well structured electronic environment.

Our electronic environment has permitted to precise the conditions for a good use of the gun either at room temperature field emission or in temperature field emission mode. This environment has also permitted to show the possibility of stabilizing the beam current by driving the extracting voltage with the emitted current fluctuations.

The extracting voltage generator exhibits an instability of $6 \mathrm{ppm} / \mathrm{min}$. and a peak-to-peak ripple of $4 \mathrm{ppm}$. This generator allows to polarize the tip with respect to the anode either negatively for electron emission or positively for the tip remolding.

The device which assumes the various heat treatment of the tip provides a current the relative stability of which is better than $100 \mathrm{ppm}$. The tip can be continuously heated at a well defined temperature during the remolding, or during the T.F. emission. In contrast, the cleaning of the tip requires pulses 
heating. The protection of the tip against the disruptive discharges has been carefully treated. The use of particularly well adapted components also insures an efficient protection of the whole environment. It is clear, that another structure of the gun, as for instance the tetrode gun would make this protection easier.

This assembly which must be polarized at the electron accelerating potential, has been set in a tank, in which the insulation if insured by pressurized freon 12. The control of the gun parameters is done by the optical fiber remote control system.

In a first time, this work has been followed by the adaptation of the electronic environment, on a field emission gun, that equips one electron microscope of our laboratory [9] then by its adaptation on the 1.6 MV STEM.

It is obvious that our approach of the problem related to the correction of the fluctuations of the current emitted by a field emission gun is appreciably different from the one which consists in compensating these fluctuations by acting on the gain of the video signal [15]. Our stabilization is particularly interesting when the image is formed on a photoplate as in conventionnal electron microscopy and, if used in scanning electron microscope, it allows to keep the signal to noise ratio at a fixed value all along any recording. However the other method is obviously more easily operated.

\section{References}

[1] Crewe, A. V., Wall, J. and Welter, L. M., J. Appl. Phys. 39 (1968) 5861.

[2] Troyon, M., Thesis, Reims, France (1977).

[3] Pitaval, M., Thesis, Lyon, France (1977).

[4] Denizart, M., Thesis, Toulouse, France (1981).

[5] Veneklasen, L., Optik 36 (1972) 410.

[6] LeWIS, R. N., Jung, E. A., Welter, L. M., VAN LoON, L. S. and Chapman, G. L., Rev. Sci. Instrum. 39 (1968) 1522.

[7] Lorrain, P., Becque, J. and Gilmore, P., Com. J. Phys. 35 (1957) 299.

[8] Nomura, S. and Komoda, T., Proc. of 6th Annual Scanning Electron Microscopy Symposium, Chicago, (1973).
[9] Denizart, M., Roques, S., Sonier, F., Jouffrey, B. and Trinquier, J., Ultramicros. 7 (1981) 65.

[10] Liang, K., Thesis, Toulouse, France (1982).

[11] Liang, K., Pinna, H., Denizart, M., Jouffrey, B., J. Micr. Spectrosc. Electron 8 (1983).

[12] Delong, A., Electron Micros. 1 (1982) 343.

[13] Roques, S., Denizart, M. and Sonier, F., Optick 1 (1983) 51.

[14] Swanson, L. W. and Martin, N. A., J. Appl. Phys. 46 (1975) 2029.

[15] Morin, P., Rolland, C., Pitaval, M. and Vicario, E., Revue Phys. Appl. 13 (1978) 39. 